\title{
Violence in health care settings: rethinking actions
}

\author{
Violência em ambientes de cuidados à saúde: repensando ações \\ Violencia en ambientes de atención a la salud: repensando acciones
}

\begin{abstract}
Hugo Fernandes', Danila Cristina Paquier Sala', Ana Lúcia de Moraes Horta'
' Universidade Federal de São Paulo, Paulista Nursing School. São Paulo, Brazil.
\end{abstract}

How to cite this article:

Fernandes $\mathrm{H}$, Sala DCP, Horta ALM. Violence in health care settings: rethinking actions.

Rev Bras Enferm [Internet]. 2018;71(5):2599-601. DOI: http://dx.doi.org/10.1590/0034-7167-2017-0882

\author{
Submission: 12-15-2017 Approval: 04-13-2018
}

\begin{abstract}
Objective: To present a reflection on the forms of violence in health care settings and on preventive actions. Method: This is a theoretical reflection about the phenomenon of violence and its possible coping actions. Results: Nurses and other professionals working in health care environments may experience situations of aggression and disrespect through institutional or managerial violence, horizontal violence and patient violence. Final considerations: Violent practices are not applicable in any workplace, especially in care settings. Actions or measures of control should be taken in pursuit of healthier environments and in harmony with the culture of peace.
\end{abstract}

Descriptors: Violence; Health Services; Health Personnel; Nursing; Health Management.

\section{RESUMO}

Objetivo: Apresentar reflexão sobre as formas de violência em ambientes de cuidados à saúde e sobre as ações para prevenção. Método: Trata-se de uma reflexão teórica acerca do fenômeno da violência e suas possíveis ações de enfrentamento. Resultados: Enfermeiros e outros profissionais que atuam em ambientes de cuidado à saúde podem vivenciar situações de agressão e desrespeito por meio da violência institucional ou gerencial, da violência horizontal e da violência dos pacientes. Considerações finais: As práticas violentas não são cabíveis em quaisquer locais de trabalho, especialmente em ambientes destinados ao cuidado. Ações ou medidas de controle devem ser adotadas em busca de ambientes mais saudáveis e em consonância com a cultura de paz.

Descritores: Violência; Serviços de Saúde; Pessoal de Saúde; Enfermagem; Gestão em Saúde.

\section{RESUMEN}

Objetivo: Presentar reflexión sobre las formas de violencia en ambientes de atención a la salud y sobre las acciones para prevención. Método: Es una reflexión teórica acerca del fenómeno de la violencia y sus posibles acciones de enfrentamiento. Resultados: Enfermeros y otros profesionales que actúan en ambientes de cuidado a la salud pueden experimentar situaciones de agresión y falta de respeto a través de la violencia institucional o gerencial, la violencia horizontal y la violencia de los pacientes. Consideraciones finales: Las prácticas violentas no se aceptan en cualquier lugar de trabajo, especialmente en ambientes destinados al cuidado. Las acciones o medidas de control deben ser adoptadas en busca de ambientes más saludables y en consonancia con la cultura de paz.

Descriptores: Violencia; Servicios de Salud; Personal de Salud; Enfermería; Gestión de la Salud. 


\section{INTRODUCTION}

Violence in health care settings has become a worldwide concern regardless of the economic and cultural characteristics of each country. Scientists, researchers, managers and professionals are restless regarding the occurrences and their repercussions on victims and witnesses. The issue tends to be concealed or camouflaged by professionals and organizations for several reasons like shame, damage to the image or even by undermining the matter. However, normative approaches for understanding violence in health services must be questioned since these are, a priori, places where one works in search of encouragement, care and recovery, hence not associated with environments linked to forms of aggression.

In countries such as Canada and the United States of America, nurses are often victims of physical, moral, psychic and even sexual violence during the exercise of their profession, and offenders are patients, family members, bosses and co-workers. Nursing is considered the second profession at most risk of violence, behind only police officers. In fact, data may be even more alarming, since nurses often do not communicate or report cases of violence, because they tend to naturalize these experiences as 'part of the job' ${ }^{\prime(1)}$. Not far from this reality, emerging countries experience such problems, but still with little visibility or little organization of research data.

Acting in health care environments involves dealing with important stressful demands, such as intense work rhythm, sometimes unfair sharing of activities, insufficient human or material resources to meet demands, rigid hierarchical relationships, strictly following protocols, norms and routines, among other situations that not always favor a healthy coping by workers, patients and families ${ }^{(1-3)}$. Thus, all actors throughout the care process can be targets or instruments of power and violence technologies.

The aim of this article is to present a reflection about the forms of violence and the preventive actions in health care settings.

\section{DEVELOPMENT}

When considering the issue, perhaps the first manifestation that comes to mind is 'institutional and managerial violence' presented as hostile practices, aggressions (physical, emotional, verbal, sexual), negligence or intentional act committed by an institution or by whom is representing it at any given time with the purpose of profit or advantage, and demoralization of those considered inferior ${ }^{(3)}$. That is, it is closely related to the conjunctures of power, oppressors and the oppressed.

Situations of low organizational tolerance in hospitals and other services, expressions of racism, disrespect to cultures and ethnicity, and the vexatious exposure of workers, among other practices, are common forms of this kind of violence. Often, services and managers argue that the blame for aggression or institutional violence lies in larger cultural aspects often escaping administrative boundaries. Thus, the arguments and guilty ones change according to the needs, which generates frequent impunity. The political-administrative response to institutional offense and abuse has been replaced by blaming individuals, which favors dominant corporations while challenging the resistance of health professions to the erosion of identity and values $^{(1-3)}$. However, institutional violence is not only towards professionals, but also directed to users in explicit or silent ways, and almost always to the most vulnerable. Rites, bureaucratic processes, difficulties in accessing services or treatments can be harmful forms to those assisted. Thus, institutional violence can fall on those who care for and who are cared for, even though in different ways ${ }^{(3-4)}$.

Equally alarming is 'horizontal violence', in which victims and perpetrators are from the same profession or interrelated professions. Most professions acting in health care environments must be performed in a team, because there is interdependence of actions for therapeutic success or efficient and safe care. However, in addition to managerial skills, working together provides the need to respect differences, potentialities and limitations of each member. Sometimes low empathy, noisy communication, and devaluation of workers' unique knowledge and practices can lead to 'destructive behaviors in health work' such as incivility, intolerance, psychic, physical, and even sexual violence.

As if that were not enough, another frequent form of violence encountered by nurses and other professionals in health care settings is 'patient violence'. In general, aggressions perpetrated by patients, relatives or companions are not performed by deliberate cruelty, but almost always as extreme impulses in the face of delays in care, care offer far away from real needs, lack of human resources, among others ${ }^{(1-4)}$. However, the violent behavior of health service users should not be naturalized or ignored. Every form of violence must be studied and repelled ${ }^{(3-6)}$.

\section{ACTIONS TO REDUCE VIOLENCE IN HEALTH CARE SETTINGS}

Given this complex scenario, the planning and implementation of interventions that can prevent and reduce violence is fundamental by using intersectoral and multidisciplinary approaches that involve all professionals, stimulate commitment and responsibility in the preservation of rights and construction of a work environment involved in a culture of peace.

The aim of actions based on the culture of peace is to build structures and social relations based on justice, equality, respect, freedom and the absence of any type of violence ${ }^{(7)}$. They value dialogue and mediation rather than conflicts, build collective actions in synergy with the various actors, whether users, professionals, or even approaches to work organization.

One of the strategies that facilitate the decrease of violence in customer service environments is the development of active listening, which involves being attentive to the needs and understanding the context of what is being said or requested. Therefore, it is important to realize that the user has a history, is part of a family and lives in a community full of beliefs, values, social roles and legacies. Thus, investing in communication with those involved in this care helps to individualize assistance in order to co-construct care that favors meeting the needs of the client, the family, the caregiver, and of professionals, and the health team will have the role of mediator. This way, the necessary empathy that facilitates the benefit of this meeting for both 
the team and users may be developed, as long as professionals believe this is also part of their activities and are valued for it.

Based on the use of techniques of communication and empathy development, it is important that professionals seek to understand the needs, competence and potentiality of users and their families in order to try to create strategies for effective resolution of demands. The development of a complex vision of the phenomenon includes actions beyond user embracement in order to expand the bonding and seek the listening of subjectivity related to the needs of those involved in the process ${ }^{(8)}$.

Health services professionals and users suffer from the results derived from the work organization in health institutions, which are related intrinsically to the management model. However, regardless of the model of service organization, some measures can be adopted by all health institutions to tackle violence, namely: monitoring and surveillance of acts of violence; embracement of victims of violence at work; creation of an internal commission against violence; leadership training; and structuring of surveillance and institutional security services ${ }^{(6)}$.

The search for a pleasant work environment with mutual respect and solidarity adds potential for conflict resolution and minimization of risks of violence. One of the strategies to this end can be the use of participatory management, in which all workers have a voice in decisions and planning of actions ${ }^{(6,9)}$.

The object of this manuscript was not to end the discussion on all interventions for tackling violence in health services. All citizens should seek to intervene in this cycle in order to change and reduce rates of violence at work.

\section{FINAL CONSIDERATIONS}

The debate about the problem is desirable, because exposure to violence has been linked to health problems in nursing professionals - physical damage, emotional manifestations, psychic disorders and diseases - and influences workers' performance and their social dimensions.

Rethinking aggression, whatever it may be, seems to be the impetus for leaving comfort zones that privilege 'blame' and deny co-responsibility and emergence of knowledge. Actions or measures adopted in the face of the phenomenon should privilege the principles of a culture of peace and well-being of all actors involved.

\section{REFERENCES}

1. Holmes D, Rudge T, Perron A. (Re)Thinking violence in health care setting: a critical approach. New York: Routledge; 2012.

2. Bordignon M, Monteiro MI. Violence in the workplace in Nursing: consequences overview. Rev Bras Enferm[Internet]. 2016[cited 2018 Jan 26];69(5):939-42. Available from: http://www.scielo.br/pdf/reben/v69n5/en_0034-7167-reben-69-05-0996.pdf

3. Azeredo YN, Schraiber LB. Institutional violence and humanization in health: notes to debate. Ciênc Saúde Colet[Internet]. 2017 [cited 2018 Jan 26];22(9):3013-22. Available from: http://www.scielo.br/pdf/csc/v22n9/en_1413-8123-csc-22-09-3013.pdf

4. Oliveira RM, Silva LMS, Guedes MVC, Oliveira ACS, Sánchez RG, Torres RAM. Analyzing the concept of disruptive behavior in healthcare work: an integrative review. Rev Esc Enferm USP[Internet]. 2016[cited 2018 Jan 26];50(4):690-9. Available from: http:// dx.doi.org/10.1590/S0080-623420160000500021

5. Silveira J, Karino ME, Martins JT, Galdino MJQ, Trevisan GS. Violence at work and measures for self-protection: nursing staff conception. J Nurs Health[Internet]. 2016[cited 2018 Jan 27];6(3):436-46. Available from: https://periodicos.ufpel.edu.br/ojs2/ index.php/enfermagem/article/view/8387/6921

6. Baptista PCP. Violência no trabalho: guia de prevenção para os profissionais de enfermagem. São Paulo: COREN-SP; 2017.

7. Von C. Cultura de Paz: o que indivíduos, grupos, escolas e organizações podem fazer pela paz no mundo. 2 ed. São Paulo: Peirópolis; 2013.

8. Santos DS, Mishima SM, Merhy EE. Work process in Family Health Program: the potential of subjectivity of care for reconfiguration of the care model. Ciênc Saúde Colet[Internet]. 2018[cited 2018 Feb 02];23(3). Available from: http://doi.org/10.1590/1413-81232018233.03102016

9. Freire MT, Rodrigues MP, Silva GSN, Melo RHV, Vilar RLA. Worker's voice regarding participatory management in a large hospital. Rev Bras Inov Tecnol Saúde[Internet]. 2014[cited 2018 Feb 02];4(4):34-54. Available from: https://periodicos.ufrn.br/reb/article/ view/5896/5105 